\title{
RATIONALITY AND REASONABLENESS IN LEGAL THEORY
}

\author{
RACIONALIDAD Y RAZONABILIDAD \\ EN LA TEORÍA JURÍDICA
}

\author{
Carlos MONTEMAYOR*
}

Resumen:

En este trabajo se examina el ensayo de Guillermo Lariguet intitulado "Analytical Legal Philosophy Reloaded", y se ofrecen dos interpretaciones de su proyecto de "renovar" la filosofia analítica del derecho. En primer lugar se sostiene que una lectura naturalista del proyecto es injustificada, y que la vía más prometedora de interpretar su propuesta es en términos una agenda metodológica más ambiciosa, la cual es análoga al criticismo metodológico exhaustivo imaginado por Jürgen Habermas en algunos de sus trabajos, en los que centra su acción comunicativa. La "razonabilidad" de la propuesta, como la denomino, es una invitación a revitalizar y enriquecer no sólo la filosofia jurídica, sino el discurso filosófico en general; además muestra que la "renovación" de la filosofía del derecho no puede ser entendida como un proyecto que se origine únicamente desde el interior de la filosofia jurídica.

\section{Palabras clave:}

Filosofia juridica, racionalidad, razonabilidad, naturalismo filosófico, acción comunicativa.

\footnotetext{
* Assistant Professor, San Francisco State University-Deparment of Philosophy, cmontema@sfsu.edu
} 
Esta revista forma parte del acervo de la Biblioteca Jurídica Virtual del Instituto de Investigaciones Jurídicas de la UNAM

Abstract:

This paper examines Guillermo Lariguet's paper 'Analytical Legal Philosophy Reloaded,' offering two interpretations of the 'reloading' project. The paper argues that a naturalistic reading of the project is unmotivated and that a more promising way of interpreting Lariguet's proposal is in terms of a rather ambitious methodological agenda, which is analogous to the broadly encompassing methodological criticism envisioned by Jürgen Habermas in some of his work, which centers on communicative action. This 'reasonableness' proposal, as I shall call it, is a plea to invigorate and enrich not just legal philosophy, but philosophical discourse in general, and shows that the reloading of legal philosophy cannot be understood as a project that originates only from within legal philosophy.

Keywords:

Legal Philosophy, Rationality, Reasonableness, Philosophical Naturalism, Communicative Action. 
Esta revista forma parte del acervo de la Biblioteca Jurídica Virtual del Instituto de Investigaciones Jurídicas de la UNAM www.juridicas.unam.mx

http://biblio.juridicas.unam.mx

RATIONALITY AND REASONABLENESS IN LEGAL THEORY

SUMmARY: I. Introduction. II. 'Reloading' as a Methodological Project Concerning Rationality. III. 'Reloading' as Critique and Reasonableness. IV. References.

\section{INTRODUCTION}

As Guillermo Lariguet explicitly states in his paper 'Analytic Legal Philosophy Reloaded,' he aims at presenting a new approach (or perspective) to debates in legal philosophy, rather than offering conclusive reasons in favor of a specific view or theory within legal philosophy. In other words, by the author's own admission, the paper does not engage with specific theses or views in order to criticize or support them. Rather, the paper aims at a more ambitious and less constrained project: on the one hand expanding the intellectual frontiers of legal philosophy and on the other hand reframing current debates that are too arid, arcane, and ultimately inane. This is the project of reloading legal philosophy. According to Lariguet, the project of reframing debates to make them more insightful and consequential depends on a criticism of legal positivism and its agenda of neatly separating legal issues from moral ones. The project of expanding the intellectual frontiers of legal philosophy, however, seems to depend on an active and thorough engagement with culture and intellectual history.

How exactly could these reframing and enriching projects reload legal philosophy? Perhaps, the author says, by bringing in considerations that should be central to legal theorizing, but which have been neglected because of self-imposed theoretical constraints. If we changed some aspects of the methodological agenda that determines current legal philosophy (such as rejecting any positivistic methodology) one could foster more insightful exchanges between legal philosophy and other disciplines, thereby identifying areas of inquiry which are silenced because of unfounded and too restrictive methodological assumptions. There are many areas of inquiry that could help reload legal 
Esta revista forma parte del acervo de la Biblioteca Jurídica Virtual del Instituto de Investigaciones Jurídicas de la UNAM www.juridicas.unam.mx

http://biblio.juridicas.unam.mx

\section{CARLOS MONTEMAYOR}

philosophy, such as political science, morality, spirituality, and literature. ${ }^{1}$

While methodology in legal theory is an extremely important topic, I believe that there is a constant ambiguity throughout Lariguet's paper concerning the role of philosophy, with all its sub-disciplines, particularly with respect to how exactly the reloading is supposed to occur. At several points Lariguet suggests that legal philosophers need to be more curious and expand their boundaries of inquiry, condemning dogmatic delineations such as the demarcation between morality and legal norms. The ambiguity I shall focus on concerns two different ways in which philosophy (including legal philosophy) can engage other disciplines. The purpose of this paper is to define two senses of the 'reloading' project in terms of the distinction between a naturalistic approach to rationality and a more ambitious approach to reasonableness. I shall argue that both interpretations indicate problems of methodology and scope in legal theory, and that Lariguet's main point is best understood according to what I shall describe as the issue of the scope of legal theorizing in terms of reasonableness, which needs to be defined in a lot more detail by Lariguet for the 'reloading' metaphor to be theoretically fruitful, for reasons I explain below.

\section{II. 'Reloading' as a Methodological Project CONCERNING RATIONALITY}

Philosophical methodology has increasingly become an area of interest and it features centrally in many recent dis-

1 I shall focus on methodological issues because I believe that methodology is the main topic of Lariguet's article. It seems fundamental, for instance, to the distinctions he introduces between theorists with legal training and those with philosophical training (i.e., legal-philosophy jurists, legal-philosophy philosophers and philosophy philosophers). I will not discuss these distinctions for the sake of clarity and conciseness, and will instead focus on the more fundamental methodological considerations of Lariguet's paper. 
Esta revista forma parte del acervo de la Biblioteca Jurídica Virtual del Instituto de Investigaciones Jurídicas de la UNAM www.juridicas.unam.mx

http://biblio.juridicas.unam.mx

RATIONALITY AND REASONABLENESS IN LEGAL THEORY

cussions concerning meta-philosophy. The topics include, for instance, the adequacy of intuitions as evidence to arrive at philosophical conclusions and the use of psychological experiments as crucial tools in philosophical investigations. Several methodological issues within legal theory belong to this category of meta-philosophical inquiry, and include the role of findings in neuroscience for theories of criminal intent and intentional action more generally. These meta-philosophical efforts are all clearly continuous with the naturalistic project that finds its most extreme version in the Quinean replacement thesis, which states, in the case of epistemology, that philosophical inquiries into the nature of knowledge will become a chapter of empirical psychology.

One way of interpreting the reloading project that Lariguet advocates is by construing it as a methodological program in line with philosophical naturalism (construed weakly, with empirically informed philosophy as arbiter or strongly, with science as sole arbiter). The paper frequently raises issues that could easily be interpreted as largely methodological in this sense. For instance, at several points in the paper the author complains about how legal philosophy is very insular, partly because of the negative impact that legal positivism, and its goal of achieving a theory that demarcates legal from moral issues, has had in legal theory. Lariguet urges theorists to enhance and enrich the connections of legal theory with morality and political theory. Ronald Dworkin, for instance, is praised for not accepting the positivistic demarcation between law and morality, and for enriching his theory with moral and practical considerations. Because of these statements by Lariguet, moral psychology and psychology in general must surely be part of the enhancement and enrichment required to reload legal philosophy. This kind of enrichment certainly happened in moral philosophy, which questioned aprioristic reasoning and favored less armchair approaches. 
Esta revista forma parte del acervo de la Biblioteca Jurídica Virtual del Instituto de Investigaciones Jurídicas de la UNAM www.juridicas.unam.mx

http://biblio.juridicas.unam.mx

CARLOS MONTEMAYOR

If this is the way to interpret the reloading program, then it is not very well motivated because there have been several (very detailed) proposals to make such connections with other disciplines for at least more than a decade, with a strongly interdisciplinary approach. In legal theory, one can think of the work of John Mikhail, ${ }^{2}$ for example, which focuses on John Rawls' linguistic analogy. In moral psychology, Stephen Stich $^{3}$ denounced the inadequacy of reflective equilibrium, Gilbert Harman ${ }^{4}$ questioned the existence of character traits, and John Doris ${ }^{5}$ denied the robustness of such traits, as well as their stability and explanatory value for a theory of moral virtue based on empirical research.

Kantian or rule-based accounts of normatively guided belief formation can similarly be challenged by analogous findings, because they demonstrate that human capacities do not comport with these normative constraints and cannot even be used for virtue epistemology as stable epistemic traits. A classic example of this empirical criticism with profound implications for philosophy is the research that led to the establishment of behavioral economics. The standard interpretation of the evidence produced by the work of Khaneman and Tversky, for instance, is that human rationality produces false belief in a vast amount of circumstances and is inordinately susceptible to the presence of irrelevant or trivial stimuli. Recently, the vast amount of findin

2 Mikhail, J., Elements of Moral Cognition: Rawls' Linguistic Analogy and the Cognitive Science of Moral and Legal Judgment, New York, Cambridge University Press, 2011.

3 Stich, Stephen, "Reflective Equilibrium, Analytic Epistemology and the Problem of Cognitive Diversity", Synthese, No. 74, 1988, pp. 391-413.

4 Harman, Gilbert, "The nonexistence of character traits", Proceedings of the Aristotelian Society, Vol. 100, No. 1, 2000, pp. 223-226.

5 Doris, John, Lack of Character: Personality and Moral Behavior. Cambridge, Cambridge University Press, 2002. 
Esta revista forma parte del acervo de la Biblioteca Jurídica Virtual del Instituto de Investigaciones Jurídicas de la UNAM www.juridicas.unam.mx

http://biblio.juridicas.unam.mx

RATIONALITY AND REASONABLENESS IN LEGAL THEORY

findings supporting human irrationality has led Kahneman 6 to argue that there are two systems for reasoning. More accurately, he says that these two systems (systems 1 and 2) are useful fictions that capture two ways in which the brain engages with problem solving (of the kind that is indispensable for idealized economic behavior) as well as truth-evaluation, in a variety of situations. I shall describe this proposal in detail because of its importance for philosophical methodology, which makes it an ideal candidate for enriching and reloading legal philosophy.

Kahneman describes experiments suggesting the existence of a fast, flexible, but unreliable system that in many cases trumps a slow, consciously demanding and reliable system. The fast system evolved to respond quickly to either urgent or typical situations, and is responsible for much of our success as a species. The slow system is more cautious and examines the nature of problems step by step, in a more reflective and meticulous manner. Kahneman says it is a mistake to associate human rationality with system 2 alone (as is assumed in prescriptive accounts of human rationality and decision making) because system 1 trumps system 2 very frequently. These findings on the relationship between systems 1 and 2 speak against stable capacities for ideal rationality across many conditions. System 2 is extremely energy consuming and, actually, lazy. These two aspects of system 2 are captured in a variety of experiments in which the quick and erroneous epistemic deliverances of system 1 prevail over the more stable epistemic processing of system 2. Moreover, even training seems to be of no help because it seems that this is just how we are "wired." Kahneman says that we cannot overcome some of the troubling biases that normally guide our decisions and actions. The conflict between these systems is not, according to Kahneman, a battle among equals (between good and bad

\footnotetext{
6 Kahneman, Daniel, Thinking Fast and Slow, New York, Farrar, Straus and Giroux, 2011.
} 
Esta revista forma parte del acervo de la Biblioteca Jurídica Virtual del Instituto de Investigaciones Jurídicas de la UNAM www.juridicas.unam.mx

http://biblio.juridicas.unam.mx

\section{CARLOS MONTEMAYOR}

reasoning). Rather, system 2 is almost always willing to give up. 7

While there is certainly impetus to promote a naturalistic approach in legal philosophy, it is unclear that such approach will result in the type of hermeneutic engagement with other disciplines that Lariguet wants. In fact, the consequences of reloading legal theory with empirical results might be largely skeptical and suggest that legal theory must not assume highly reflective human subjects, or that findings in neuroscience may be much more important for legal theory than reflections on the connection between legal theory and literature. In other words, this would be a largely skeptical and, at least in one sense of the word, positivistic outcome, because science would be at the helm of the project of reloading legal philosophy.

In any case, as mentioned, if this naturalistic project is the relevant sense of 'reloading' intended by Lariguet, then his claims can hardly be justified because of the very substantial amount of papers and theories devoted to such project in recent years (Mikhail's work is only one among many other notable examples). Legal philosophers and theorists have really engaged with scientific disciplines, particularly the cognitive sciences. There are, for instance, several research programs exploring the implications of findings in neuroscience for legal theory. Findings in cognitive science show that legal theory assumes unrealistic human capacities for responsibility across many situations, that neuroimaging may become an incredibly powerful source of evidence in trials, with drastically revisionist and altering consequences for legal theory respectively. The thesis that this

7 See Gigerenzer for a critical response to this skeptical interpretation of the findings. It is important to highlight that Gigerenzer supports the revisionary project initiated by Kahneman and Tversky, and admits that the findings challenge the previous idealistic standards for rationality espoused prominently by Bayesian theories. Gigerenzer, Gerd, Rationality for Mortals: How People Cope with Uncertainty, New York, Oxford University Press, 2008.

PROBLEMA

Anuario de Filosofia y Teoría del Derecho, Núm. 8, enero-diciembre de 2014, pp. 39-51 
Esta revista forma parte del acervo de la Biblioteca Jurídica Virtual del Instituto de Investigaciones Jurídicas de la UNAM www.juridicas.unam.mx

http://biblio.juridicas.unam.mx

RATIONALITY AND REASONABLENESS IN LEGAL THEORY

kind of reloading will revitalize legal theory in the way Lariguet wants is problematic, but I shall not argue for this here. It suffices to say that there are several substantial research programs addressing this sense of 'reloading'.

Since this sense of 'reloading' is not a particularly plausible one because it can hardly be motivated or justified as a new approach that will enrich legal theory, attributing it to Lariguet would be an uncharitable way of interpreting his proposal. A more promising way of interpreting his proposal is in terms of a rather ambitious methodological agenda, similar to the broadly encompassing methodological criticism envisioned by Jürgen Habermas, which centers on communicative action. This 'reasonableness' proposal, as I shall call it, is a plea to invigorate and enrich not just legal philosophy, but philosophy in general, and shows that the reloading of legal philosophy cannot be understood as a project that needs to happen within legal philosophy but must include the discipline of philosophy as a whole.

\section{III. 'Reloading' as CRitique And Reasonableness}

To focus the analysis of the reloading proposal in terms of an over-encompassing rethinking of philosophy I shall focus on Habermas' (1968) discussion ${ }^{8}$ of the role of human interests in the edification of knowledge. Instead of offering a detailed presentation of the arguments that Habermas provides, I would like to draw analogies between the project he describes and Lariguet's proposal. The reason for doing this is that Lariguet says he wants to offer a perspective on how legal philosophy should be reconceived and so I shall focus on the perspective Habermas offers with respect to how philosophy should be reconceived. I aim at clarifying why legal theory cannot be reloaded in isolation, or independently from other areas in philosophy.

8 Habermas, Jürgen, Knowledge and Practical Interests, tr. by Jeremy J. Shapiro, Boston MA, Beacon Press, 1971, German edition first published in 1968. 
Esta revista forma parte del acervo de la Biblioteca Jurídica Virtual del Instituto de Investigaciones Jurídicas de la UNAM www.juridicas.unam.mx

http://biblio.juridicas.unam.mx

CARLOS MONTEMAYOR

An important feature of Habermas' proposal is that he challenges the notion of scientific positivism (and naïve scientism in general) as the only rational approach to knowledge. While it is not very clear that Lariguet proposes this thorough revision of philosophy and human knowledge, there are many aspects of Habermas' proposal that resonate with a lot of what Lariguet says in his paper. I shall quote Habermas at length for the purposes of thoroughness. For instance, with respect to the positivist attitude in philosophy (which is arguably associated with the type of naturalistic attitude described in the previous section) $\mathrm{Ha}-$ bermas says: ${ }^{9}$

Positivism certainly still expresses a philosophical position with regard to science, for the scientistic self-understanding of the sciences that it articulates does not coincide with science itself. But by making a dogma of the sciences' belief in themselves, positivism assumes the prohibitive function of protecting scientific inquiry from epistemological self-reflection. Positivism is philosophical only insofar as it is necessary for the immunization of the sciences against philosophy. For methodology by itself does not suffice; it must also prove itself as epistemology or, better, as its legitimate and reliable executor.

The 'reloading' project can be understood as a self-reflective exercise in connecting the sciences (and scientifically informed philosophy) with the broader human interests that we have as a global community. While science provides a rational framework to communicate and interact, such that philosophy can greatly benefit from such framework, reasonableness and understanding cannot depend exclusively on such framework. Communicative rationality (or reasonableness, as opposed to instrumental and theoretical rationality) requires a type of reflection and philosophical insight that cannot be replaced by the methodologies of science. This is a central consideration underlying Habermas'

9 Ibidem, p. 67. 
Esta revista forma parte del acervo de la Biblioteca Jurídica Virtual del Instituto de Investigaciones Jurídicas de la UNAM www.juridicas.unam.mx

http://biblio.juridicas.unam.mx

RATIONALITY AND REASONABLENESS IN LEGAL THEORY

objections to positivism as well as his plea for a more ambitious philosophical methodology. He explains: ${ }^{10}$

The connection of knowledge and interest that we have discovered methodologically can be explained and preserved against misinterpretation through recourse to the concept of an interest of reason, developed by Kant and especially by Fichte.

The interest of reason behind a philosophical view is what integrates a set of claims into a genuinely understood perspective on reality-a perspective that one can make one's own approach to reality. For this (Sellarsian) reason, Habermas refers to Fichte's statement that a "philosophical system is not a pile of junk that could be discarded or retained at our whim." 11 Habermas clarifies the role of interests in the construction of communicative action and knowledge as follows: ${ }^{12}$

The concept of "interest" is not meant to imply a naturalistic reduction of transcendental-logical properties to empirical ones. Indeed, it is meant to prevent just such a reduction. Knowledge-constitutive interests mediate the natural history of the human species with the logic of its self-formative process. [...] But they cannot be employed to reduce this logic to any sort of natural basis. I term interests the basic orientations rooted in specific fundamental conditions of the possible reproduction and self-constitution of the human species, namely work and interaction.

These reflections are certainly relevant for the reloading project envisioned by Lariguet. One may even argue that this historically informed and highly ambitious reflective project is exactly the kind of perspective Lariguet wants to offer. A proper understanding of the reloading project in

10 Ibidem, p. 189.

11 Ibidem, p. 209.

12 Ibidem, p. 196. 
Esta revista forma parte del acervo de la Biblioteca Jurídica Virtual del Instituto de Investigaciones Jurídicas de la UNAM www.juridicas.unam.mx

http://biblio.juridicas.unam.mx

CARLOS MONTEMAYOR

terms of reasonableness leads to the conclusion that indeed, legal philosophy is central to articulate the most basic interests and claims to knowledge of human societies, currently and historically, requiring the interaction between many areas of philosophy and specific areas of legal theory and jurisprudence (e.g., constitutional law, history of law and criminal law).

Findings in neuroscience and biology will be crucial to understand our place as a species, but they will not suffice to understand which normative orientation we should take as members of our communities, (not only based on maximizing principles for rationality, but also based on interests that we share as humans). Interests based on how humans work and interact, provided that they are not the result of manipulation, provide the basis for communicative action. Legal theory, reloaded by making these interests central, would play an important role in the philosophical program sketched by Habermas. If this is the kind of reloading that Lariguet has in mind, it is certainly an urgent and important one. It is unclear, however, how exactly this program is going to produce such a comprehensive worldview and, in the specific case of Lariguet's proposal, why would it require the reloading of just legal theory, rather than a reloading of philosophy in general.

Although this construal of the reloading project in terms of reasonableness is more promising, it is also problematic because of the very substantial theoretical challenges that it confronts, particularly concerning the integration of alternative points of views with the scientific view of the world (a problem highlighted by Wilfrid Sellars' characterization of the manifest and scientific images). So a lot more details need to be provided to fully grasp what the reloading of philosophical methodology really amounts to. A question that needs to be addressed is whether or not legal theory plays a unique role in the reloading of philosophy. In my opinion, legal philosophy has no uniquely important role to play in the reloading of philosophical methodology. Thus, I 
Esta revista forma parte del acervo de la Biblioteca Jurídica Virtual del Instituto de Investigaciones Jurídicas de la UNAM www.juridicas.unam.mx

http://biblio.juridicas.unam.mx

RATIONALITY AND REASONABLENESS IN LEGAL THEORY

believe that the best way to reload legal philosophy is by reloading the methodology of philosophy in general. If Lariguet thinks that legal philosophy must play a central role, then he needs to provide more evidence and arguments to show why this is the case.

IV. REFERENCES

DORIS, John, Lack of Character: Personality and Moral Behavior, Cambridge, Cambridge University Press, 2002.

Gigerenzer, Gerd, Rationality for Mortals: How People Cope with Uncertainty, New York, Oxford University Press, 2008.

HARMAN, Gilbert, "The Nonexistence of Character Traits", Proceedings of the Aristotelian Society, vol. 100, No. 1, 2000.

HABERMAS, Jürgen, Knowledge and Practical Interests, tr. by Jeremy J. Shapiro, Boston MA, Beacon Press, 1971, German edition first published in 1968.

KaHneman, Daniel, Thinking Fast and Slow, New York, Farrar, Straus and Giroux, 2011.

MikHAIL, J., Elements of Moral Cognition: Rawls' Linguistic Analogy and the Cognitive Science of Moral and Legal Judgment, New York, Cambridge University Press, 2011.

SCHAFFER, Jonathan, "Truth and Fundamentality: On Merrick's Truth and Ontology", Philosophical Books, Vol. 49, No. 4, 2008.

STICH, Stephen, "Reflective Equilibrium, Analytic Epistemology and the Problem of Cognitive Diversity", Synthese, No. 74, 1988. 